\title{
KEMAMPUAN BERPIKIR KRITIS SISWA DALAM MENYELESAIKAN SOAL OPERASI HIMPUNAN
}

\author{
Yantina Leba Djawa ${ }^{1}$, Elsy Senides Hana Taunu ${ }^{2}$, Mega Retno Wulandari ${ }^{3}$, Yuliana \\ Tamu Ina Nuhamara ${ }^{4 *}$, Stevvileny Angu Bima ${ }^{5}$, Iona Lisa Ndakularak ${ }^{6}$ \\ 1,2,3,4,5,6 Universitas Kristen Wira Wacana, Waingapu, Indonesia \\ *Corresponding Author: yulinuhamara@unkriswina.ac.id
}

\begin{tabular}{l}
\hline Info Artikel \\
\hline Sejarah Artikel: \\
Diterima: $20 / 12 / 2021$ \\
Direvisi : $31 / 12 / 2021$ \\
Disetujui: $02 / 01 / 2022$ \\
\hline Keywords: \\
Critical thinking skills, \\
Sets \\
\hline
\end{tabular}

Kata Kunci: Kemampuan berpikir kritis, Himpunan

\begin{abstract}
This study aims to describe critical thinking skills, identify factors that affect critical thinking skills and recommend follow-up plans to overcome students' low critical thinking ability to complete class VII set operations problems at Waingapu City Junior High School. This type of research is descriptive research with a qualitative approach. Data collection uses tests, interviews and documentation studies. The subjects in the study were 30 students of class VII junior high school in Waingapu City. The results found that the average critical thinking ability of students was 37.29 and was in the low category. There are several factors that affect students' critical thinking skills, including lack of relearning of the material that has been obtained, mastery of mathematical concepts, learning interests and students' thoroughness in working on problems. The recommendations of actions taken by teachers are reviewing the basic concepts of mathematics, designing learning devices and training students to work on story problems and learning motivation.
\end{abstract}

\begin{abstract}
Abstrak. Penelitian ini bertujuan untuk mendeskripsikan kemampuan berpikir kritis, mengidentifikasi faktor yang mempengaruhi kemampuan berpikir kritis dan merekomendasikan rencana tindak lanjut untuk mengatasi rendahnya kemampuan berpikir kritis siswa dalam menyelesaikan soal operasi himpunan kelas VII di SMP Kota Waingapu. Jenis penelitian ini adalah penelitian deskriptif dengan pendekatan kualitatif. Pengumpulan data menggunakan tes, wawancara dan studi dokumentasi. Subjek dalam penelitian yaitu 30 orang siswa kelas VII SMP di Kota Waingapu. Hasil penelitian ditemukan bahwa rata-rata kemampuan berpikir kritis siswa yaitu 37,29 dan berada di kategori rendah. Terdapat beberapa faktor yang mempengaruhi kemampuan berpikir kritis siswa, diantaranya kurangnya mempelajari kembali materi yang telah diperoleh, penguasaan konsep matematika, minat belajar dan ketelitian siswa dalam mengerjakan soal. Adapun rekomendasi tindakan yang dilakukan guru yaitu mereview konsep dasar matematika, merancang perangkat pembelajaran dan melatih siswa mengerjakan soal cerita dan motivasi belajar.
\end{abstract}

How to Cite: Djawa, Y. L., Taunu, E. S. H., Wulandari, M. R., Nuhamara, Y. T. I., Bima, S. A., \& Ndakularak, I. L. (2022). KEMAMPUAN BERPIKIR KRITIS SISWA DALAM MENYELESAIKAN SOAL OPERASI HIMPUNAN. Prima Magistra: Jurnal Ilmiah Kependidikan, 3(1), 116-122. https://doi.org/10.37478/jpm.v3i1.1483

Alamat korespondensi:

Jl. R. Soeprapto No 35, Waingapu, Kabupaten Sumba Timur, Provinsi Nusa Tenggara Timur.

(9) yulinuhamara@unkriswina.ac.id
Penerbit:

Program Studi PGSD Universitas Flores.

( primagistrauniflor@gmail.com 


\section{PENDAHULUAN}

Salah satu matapelajaran yang selalu dipelajari pada setiap jenjang pendidikan yaitu Matematika. Dengan mempelajari matematika siswa-siswa dipersiapkan dan dibakali terkait terkait kemampuan bekerjasama, inovatif, kreatif, logis dan kritis (Sulistiani \& Masrukan, 2016). Dengan mempelajari matematika, siswa tidak hanya dituntut memiliki kemampuan dasar berhitung, namun juga kemampuan bernalar secara logis dan kritis dalam memecahkan masalah (Kusumawardani et al., 2018).

Melalui kegiatan belajar mengajar dalam pembelajaran matematika siswa dapat mengembangkan kreativitasnya dan meningkatkan kemampuan berpikir serta pemahaman terhadap ppengetahuan yang baru khususnya dalam materi matematika, Selama kegiatan pembelajaran matematika siswa diwajibkan untuk meningkatkan keaktifan melalui berdiskusi, tanya jawab, berpikir kritis, menjelaskan dan mengajukan alasan pada setiap jawaban. Oleh karena itu, salah satu kemampuan yang diperlukan siswa-siswi dalam mempelajari matematika yaitu kemampuan berpikir kritis. Ketika seorang siswa-siswi memiliki kemampuan berpikir kritis maka mereka dengan sendirinya akan mampu menelaah permasalahan yang dihadapi, kemudian mencari dan menentuka penyelesaian yang tepat, logis dan bermanfaat, Dengan kata lain, siswa-siswa dapat memcari atau menentukan solusi terbaik dalam memecahkan sebuah permasalahan (Nugroho, 2017).

Kemampuan berpikir kritis merupakan proses berpikir intelektual di mana pemikir dengan sengaja menilai kualitas pemikirannya, pemikir menggunakan pemikiran yang reflektif, independen, jernih, dan rasional (Ahmatika, 2016). Ketika siswa membiasakan diri untuk berpikir kritis maka siswa bisa bersikap rasional dalam menentukan dan memilih alternatif pilihan yang terbaik untuk dirinya (Firdaus et al., 2019).

Menurut Karim \& Normaya (2015), berpikir kritis adalah berpikir rasional dalam menilai sesuatu dengan cara melakukan mengumpulkan informasi sebelum mengambil atau mengambil keputusan terhadap permasalahan tertentu. Siswa yang dapat berpikir kritis memiliki ciri khusus yaitu dapat dilihat bagaimana siswa menghadapi suatu keadaan, masalah atau pendapat. Namun, kemampuan berpikir kritis setiap siswa berbeda-beda dalam menyelesaikan masalah.

Kemampuan berpikir kritis menjadi bagian terpenting selama proses pembelajaran matematika. Dengan kemampuan tersebut diharapkan siswa mampu menyelesaikan masalah yang berkaitan dengan matematika (Lestari \& Roesdina, 2021). Hal tersebut merupakan bagian yang saling berkaitan, dimana materi matematika dipahami siswa menggunakan kemampuan berpikir kritis. Sedangkan kemampuan berpikir kritis dikembangkan dan dilatih dalam menyelesaikan masalah yang terdapat dalam materi matematika (Sulistiani \& Masrukan, 2016). Oleh karena itu, kemampuan bepikir kritis merupakan bagian terpenting dalam penyelesaian masalah di semua tingkat pendidikan (Mahmuzah, 2015).

Kemampuan berpikir siswa diukur menggunakan indikator Murphy dan Perkins yaitu (1) klarifikasi, dimana siswa mampu menuliskan diketahui dan ditanyakan, (2) asesmen, dimana siswa dapat menggunakan atau mengajukan informasi atau konsep yang relevan, (3) penyimpulan, dimana siswa mampu mencapai simpulan dari soal, (4) strategi/taktik, dimana siswa mampu menyelesaikan soal dengan runtut dan benar (Noor, 2019). Indikator-indikator berpikir kritis diharapkan dimiliki siswa karena sangat dibutuhkan dalam pembelajaran matematika (Mahmuzah, 2015). Namun, selama proses pembelajaran matematika kebanyakan siswa memiliki kemampuan berpikir kritis yang rendah. Hal ini sejalan dengan pendapat yang dikemukan oleh Sholihah \& Rejeki (2020) bahwa fakta dilapangan masih ditemui proses pembelajaran matematika di sekolah belum mengembangkan atau meningkatkan potensi kemampuan berpikir kritis siswa-siswinya.

Berlandaskan hasil penelitian Kodu \& Muzaki (2019) di SMP Swasta Rangga Rame Pada Materi Statistika menunjukkan bahwa kemampuan berpikir kritis siswa kelas IX 
masih rendah. Rendahnya kemampuan berpikir kritis siswa dapat dilihat pada saat siswa-siswi megerjakan soal yang diberikan, siswa masih kurang dalam memahami soal, membuat model matematika, dan langkah penyelesaian soal secara runtut. Kondisi tersebut juga dialami SMP di Waingapu.

Rendahnya kemampuan berpikir kritis khususnya pada operasi himpunan. Hal tersebut dikarenakan kurangnya dasar pemahaman siswa, baik itu konsep dasar ataupun materi yang diajarkan sebelumnya. Sebagian siswa belum mampu menafsirkan soal menggunakan notasi matematika, siswa kurang memahami simbol-simbol yang ada dalam materi himpunan, pengelompokan anggota himpunan dan memahami soal himpunan dalam bentuk cerita. Salah satu contoh jawaban siswa dalam mengerjakan soal operasi himpunan diukur dari indikator berpikir kritis. Kesalahan ditemukan pada saat penyelesaian soal yang diberikan. Dimana siswa diminta untuk menyelesaikan operasi himpunan, namun belum mampu mengklarifikasi dan menuliskan kesimpulan. Berdasarkan uraian masalah tersebut, maka kemampuan berpikir kritis perlu dilakukan penelitian lebih lanjut agar diberikan solusi.

Berdasarkan permasalahan yang telah dipaparkan diatas, maka penelitian ini perlu dilakukan dengan tujuan untuk mendeskripsikan dan mengidentifikasi kemampuan berpikir kritis serta merekomendasikan upaya tindak lanjut untuk mengatasi rendahnya kemampuan berpikir kritis pada materi himpunan. Beberapa penelitian yang mengkaji mengenai kemampunan berpikir kritis telah dilakukan oleh peneliti lainnya. Tetapi, penelitian yang mengkaji kemampuan berpikir kritis siswa SMP di Waingapu belum pernah dilakukankan. Selain itu, hasil penelitian ini memberikan kontribusi terkait solusi atau rekomendasi tindak lanjut guna mengatasi permasalahan rendahnya kemampuan berpikir kritis pada materi himpunan bagi siswa SMP.

\section{METODE PENELITIAN}

Pendekatan kualitatif merupakan penelitian membahas fakta atau kondisi yang terjadi dengan kata-kata atau bahasa yang diamati (Sugiyono, 2017). Sedangkan jenis penelitian kualitatif deskriptif adalah penelitian secara menyeluruh dan tepat untuk membahas suatu keadaan atau objek yang teliti (Moleong, 2017; Sugiyono, 2017).

Penelitian dilakukan di salah satu SMP di Kota Waingapu pada bulan April-Mei 2021. Teknik pengambilan subjek menggunakan purposive sampling yaitu subjek yang digunakan mengacu pada pertimbangan tertentu (Sugiyono, 2017). Subjek dalam penelitian ini sebanyak 30 siswa kelas VII yang mengerjakan soal tes.

Teknik pengumpulan data dalam penelitian ini yaitu tes tertulis, wawancara dan studi dokumen. Tes tertulis digunakan untuk mencari data terkait kemampuan berpikir kritis siswa. Wawancara dilakukan untuk mengkonfirmasi hasil tes tertulis, sedangkan studi dokumen digunakan untuk mencari data hasil belajar siswa berupa nilai ulangan harian.

Teknik analisis data yang digunakan dalam penelitian ini yaitu menggunakan model Milles \& Huberman (Sugiyono, 2017) membagi analisis data menjadi empat bagian, diantaranya adalah (1) pengumpulan data, (2) reduksi data, (3) penyajian data, (4) dan penarikan kesimpulan.

\section{HASIL DAN PEMBAHASAN}

Penelitian dilaksanakan di salah satu SMP Negeri di Kota Waingapu pada Tahun Ajaran 2020/2021. Penentuan subjek penelitian berdasarkan keputusan guru matematika yang menyarankan menggunakan 30 orang siswa kelas VII. Data yang diperoleh pada saat tes dianalisis berdasarkan indikator Murphy dan Perkins dengan tujuan untuk mendeskripsikan dan mengidentifikasi faktor yang mempengaruhi kemampuan berpikir kritis siswa dalam menyelesaikan soal operasi himpunan. Data hasil tes diperoleh rata-rata pada Tabel 1 sebagai berikut:

Tabel 1 Rata-Rata Kemampuan Berpikir Kritis Siswa

\begin{tabular}{lccc}
\hline $\begin{array}{c}\text { Indikator Berpikir } \\
\text { Kritis }\end{array}$ & Total & Nilai & Rata-rata \\
\hline Klarifikasi & 172 & 1.075 & 35,83 \\
Asesmen & 184 & 1.150 & 38,33 \\
Penyimpulan & 114 & 712,5 & 23,75 \\
Strategi/taktik & 246 & $1.537,5$ & 51,25 \\
\hline
\end{tabular}


Berdasarkan Tabel 1, ditunjukkan bahwa indikator 4 menjadi indikator yang mencapai nilai tertinggi yaitu 51,25. Indikator 2 merupakan indikator tertinggi kedua menunjukkan capaian 38,33 dimana siswa mampu menentukan konsep penyelesaian soal. Indikator 1 merupakan indikator dengan rata-rata tertinggi ketiga menunjukkan capaian 35,83 dimana siswa diharapkan mampu menyebutkan masalah yang terdapat dalam soal. Sedangkan indikator 3 merupakan indikator yang paling rendah dimana siswa memperoleh nilai yang diharapkan, dimana siswa diharapkan mampu mencapai simpulan. Indikator 3 mencapai nilai rata-rata 23,75.

Berdasarkan hasil tes menunjukkan bahwa, rerata hasil tes kemampuan berpikir kritis yaitu 37,29 dan berada pada kategori rendah. Siswa banyak melakukan kesalahan mengerjakan soal nomor 2, 3 dan 4 dimana belum mencapai klarifikasi yaitu siswa langsung menjawab soal tanpa menyebutkan informasi dalam soal.

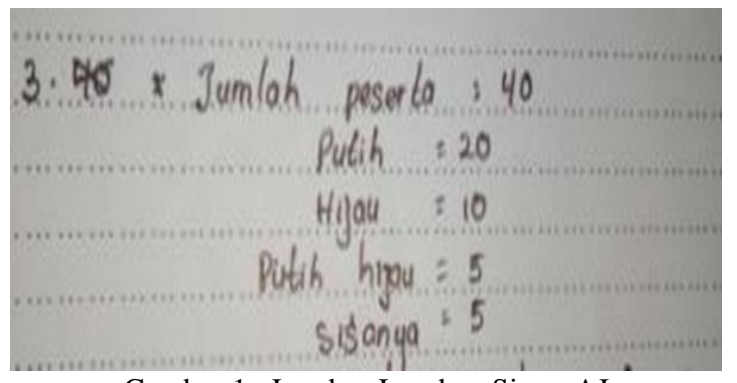

Gambar 1 : Lembar Jawaban Siswa AJ

Hasil wawancara siswa AJ juga menunjukkan bahwa siswa tersebut tidak bisa menuliskan informasi yang ada dalam soal. Sesuai dengan hasil penelitian Kodu \& Muzaki (2019) menyimpulkan siswa belum mencapai indikator ini jika siswa tidak menuliskan informasi dalam soal. Berbeda dengan hasil penelitian yang dilakukan oleh Sholihah \& Rejeki (2020) bahwa siswa mampu menyebutkan informasi yang terdapat pada soal dengan menuliskan diketahui dan ditanyakan dari soal yang diberikan.

Indikator assessment dimana siswa tidak menuliskan informasi dan menggunakan ide/konsep dalam menyelesaikan soal. Berikut ini contoh lembar jawaban siswa yang menunjukkan indikator assessment tidak menuliskan konsep dengan benar.

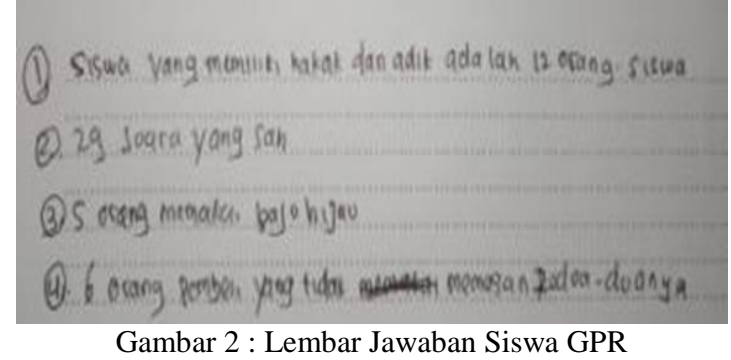

Hasil wawancara dengan siswa GPR menunjukkan bahwa siswa tersebut tidak menggunakan informasi yang ada untuk menyelesaikan soal. Berlandaskan penelitian yang dilakukan oleh Kodu \& Muzaki (2019) juga mengungkapkan siswa dengan kode S5 dan S6 tidak menuliskan dan menggunakan konsep dengan benar. Sedangkan hasil penelitian yang dilakukan oleh Ismianti et al. (2017) pada tahapan assesment siswa dapat memilih informasi dari soal yang dibutuhkan untuk menyelesaikan soal. Selain itu, siswa juga dapat menjelaskan konsep yang akan digunakan untuk menyelesaikan soal dengan menggunakan kata-kata atau idenya sendiri.

Pada indikator penyimpulan yaitu siswa terbiasa menyelesaikan soal tanpa menarik kesimpulan. Hasil konfirmasi jawaban melalui wawancara dengan siswa CJ diketahui bahwa siswa tersebut tidak menuliskan kesimpulan pada setiap jawaban soal yang diberikan. Berlandaskan penelitian yang dilakukan oleh Kodu \& Muzaki (2019) juga menyatakan siswa belum mampu membuat kesimpulan untuk semua soal.

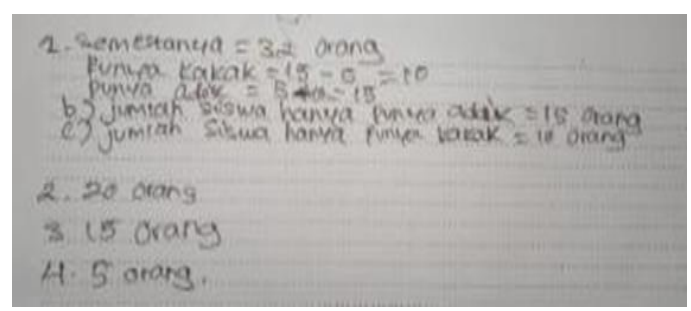

Gambar 3 : Lembar Jawaban Siswa CJ

Rendahnya strategi/taktik yaitu siswa belum menggunakan langkah-langkah penyelesaian soal dengan benar. Sejalan dengan penelitian yang dilakukan oleh Ismianti et al. (2017) menyatakan siswa dapat dikatakan mencapai indikator ini jika mampu menyelesaikan langkah-langkah penyelesaian soal dengan benar. Berdasarkan hasil wawancara dengan siswa RUR diketahui bahwa siswa tersebut tidak menggunakan cara 
lain untuk menyelasaikan soal, terutama pada soal nomor 3 .

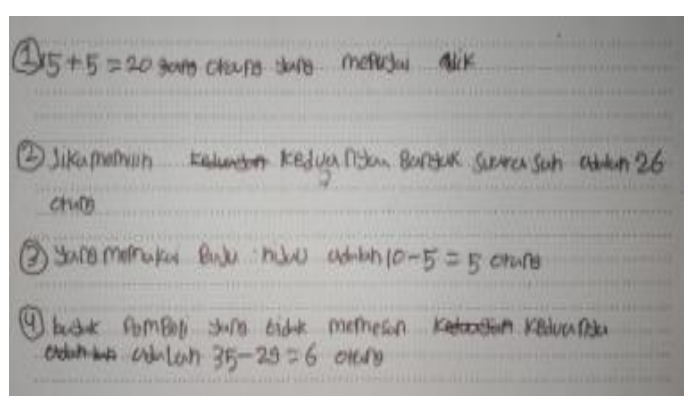

Gambar 4 : Lembar Jawaban Siswa RUR

Berlandaskan hasil deskripsi, adapun faktor yang mempengaruhi kemampuan berpikir kritis siswa yaitu: (1) Rendahnya kemampuan awal, pengetahuan pada materi sebelumnya menjadi bagian terpenting dalam pembelajaran selanjutnya. Jika siswa memiliki kemampuan awal mempermudah pemahaman siswa pada materi selanjutnya, karena dalam pembelajaran materi matematika selalu berkaitan. Hal ini juga ditemukan dalam penelitian yang telah dilakukan oleh Razak (2017) bahwa kemampuan awal yang dimiliki siswa merupakan prasyarat awal yang harus dimiliki siswa, agar proses pembelajaran dapat berjalan dengan baik.

\section{Penguasaan konsep matematika}

Siswa yang mempunyai kemampuan pemahaman konsep lebih mudah menjawab soal matematika. Hal ini sejalan dengan penelitian Kodu \& Muzaki (2019) menyatakan rendahnya penguasaan konsep matematika akan mempengaruhi kemampuan berpikir kritis siswa; dan penelitian Razak (2017) menyatakan bahwa kemampuan awal atau pengetahuan siswa terhadap materi sebelumnya akan menentukan kemampuan berpikir kritis siswa dalam memecahkan masalah matematika yang dihadapinya.

\section{Siswa tidak mempelajari kembali materi}

Mempelajari materi yang diperoleh sangat diperlukan dalam pembelajaran. Dengan mempelajari kembali materi siswa akan lebih mudah memahami materi selanjutnya. Hal ini sejalan dengan penelitian Kodu \& Muzaki (2019) menyatakan siswa lebih mudah memahami materi selanjutnya jika sering mempelajari materi sebelumnya dan dapat melatih siswa belajar mandiri tanpa bimbingan guru.

\section{Minat belajar dan ketelitian.}

Minat belajar dan ketelitian menjadi faktor penting dalam menyelesaikan masalah matematika. Dimana jika siswa tidak teliti dan terburu-buru dalam menyelesaikan soal akan mempengaruhi hasil penyelesaian matematika. Hal ini didukung penelitian oleh Siskandani et al. (2020) yang menyatakan bahwa kurangnya ketelitian siswa dalam menyelesaikan soal matematika, dikarenakan siswa tidak membaca soal secara berulang untuk memahami maksud dari soal yang diberikan. Kurangnya ketelitian siswa dalam menyelesaikan soal akan mempengaruhi kemampuan berpikir kritis yang dimilikinya.

Berdasarkan faktor yang mempengaruhi kemampuan berpikir kritis siswa, adapun rekomendasi tindakan sebagai berikut:

\section{Mereview konsep dasar matematika}

Dengan mempelajari kembali konsep dasar matematika akan melatih siswa dalam mengingat kembali materi sebelumnya. Hal ini didukung dengan penelitian oleh Razak (2017) menyatakan bahwa kemampuan awal atau pengetahuan siswa terhadap materi sebelumnya akan menentukan kemampuan berpikir kritis siswa dalam memecahkan masalah matematika yang dihadapinya. Selanjutnya penelitian Ismianti et al. (2017) juga menyatakan bahwa guru perlu memberikan penekanan pada konsep-konsep dasar matematika.

\section{Merancang perangkat pembelajaran}

Kreatif guru dalam merancang perangkat pembelajaran akan menjadi faktor penting dalam pembelajaran. Dimana perangkat pembelajaran yang digunakan akan membuat siswa terbiasa mempelajari materi berdasarkan kemampuan berpikir kritis. Didukung oleh penelitian Nuryanti et al. (2018) merancang dan mengembangkan perangkat pembelajaran salah satu faktor penting dalam meningkatkan kemampuan berpikir kritis. Selain itu, Nugroho (2017) juga berpendapat bahwa seorang guru wajib untuk terus menerus berupaya melakukan 
inovasi dalam proses belajar mengajar yang tujuan untuk mengembangkan serta meningkatkan kemampuan berpikir kritis siswa.

\section{Memberikan soal-soal dalam bentuk cerita.}

Kemampuan berpikir dapat dilatih melalui penyelesaian soal cerita. Sejalan dengan penelitian yang dilakukan Noor (2019) mengungkapkan pemberian soal-soal cerita dapat melatih siswa mengembangkan kemampuan berpikir kritis agar menjadi bekal dalam menghadapi masalah dalam kehidupan sehari-hari. Ismianti et al. (2017) menyatakan siswa sudah dibiasakan dalam memahami dan menyelesaikan setiap materi matematika dapat meningkatkan kemampuan berpikir kritis.

\section{SIMPULAN DAN SARAN}

Berlandaskan hasil dan pembahasan yang telah diuraikan, maka kesimpulannya kemampuan berpikir kritis siswa dalam menyelesaikan soal operasi himpunan ditunjukkan dengan nilai rerata 37,29 berada dikategori rendah. Berdasarkan indikator Murphy dan Perkins kemampuan siswa dalam menyelesaikan soal belum merata yaitu 1) tidak menuliskan informasi diketahui dan ditanyakan; 2) tidak menggunakan konsep dalam proses pengerjaan soal; 3) siswa tidak menuliskan penyimpulan dalam pengerjaan soal; 4) siswa tidak terbiasa melakukan proses pengerjaan soal secara runtut sehingga jawaban yang diperoleh tidak tepat.

Adapun faktor-faktor yang mempengaruhi kemampuan berpikir kritis yaitu siswa tidak mempelajari materi yang diperoleh, kurangnya pengetahuan siswa pada materi sebelumnya berupa konsep dasar matematika, minat dan ketelitian siswa. Rencana tindakan yang dilakukan oleh guru, yaitu mereview konsep dasar matematika, merancang perangkat pembelajaran, memotivasi siswa dan memberikan soal-soal cerita sehingga dapat melatih siswa mengembangkan dan menerapkan kemampuan berpikir kritis dalam kehidupan sehari-hari.

Berdasarkan hasil penelitian ini, maka peneliti mengemukakan saran yaitu bagi guru memperhatikan dan meningkatkan kemampuan siswa khususnya pada materi yang berkaitan dengan kehidupan nyata, siswa juga lebih memperhatikan proses pengerjaan soal sehingga siswa terbiasa dalam mengerjakan soal secara runtut dan peneliti selanjutnya, termotivasi untuk melengkapi kekurangan penelitian dalam menggali faktorfaktor yang mempengaruhi kemampuan berpikir kritis. Penutup berisi kesimpulan dari hasil penelitian yang dilaksanakan dan rekomendasi berdasarkan hasil penelitian.

\section{DAFTAR PUSTAKA}

Ahmatika, D. (2017). PENINGKATAN KEMAMPUAN BERPIKIR KRITIS SISWA DENGAN PENDEKATAN INQUIRY/DISCOVERY. Euclid, 3(1). Google Scholar

Firdaus, A., Nisa, L. C., \& Nadhifah, N. (2019). Kemampuan berpikir kritis siswa pada materi barisan dan deret berdasarkan gaya berpikir. Kreano, Jurnal Matematika KreatifInovatif, 10(1), 68-77. https://doi.org/10.15294/kreano.v10i1.1 7822

Ismianti, I., Yunus, J., \& Umam, K. (2017). Analisis Kemampuan Siswa Berpikir Kritis Matematika pada Materi Kubus dan Balok di Kelas VIII SMP Negeri 19 Percontohan Banda Aceh. Jurnal Ilmiah Mahasiswa Pendidikan Matematika, 2(2).

http://www.jim.unsyiah.ac.id/pendidika n-matematika/article/view/2065

Karim, K., \& Normaya, N. (2015). Kemampuan berpikir kritis siswa dalam pembelajaran dalam pembelajaran matematika dengan menggunakan model jucama di sekolah menengah pertama. EDU-MAT: Jurnal Pendidikan Matematika, 3(1).

http://dx.doi.org/10.20527/edumat.v3i1. 634

Kodu, H. I., \& Muzaki, A. (2019). ANALISIS KEMAMPUAN BERPIKIR KRITIS SISWA KELAS IX DI SMP SWASTA RANGGA RAME PADA MATERI STATISTIKA TAHUN AJARAN 2019/2020. Jurnal Penelitian Pendidikan Matematika Sumba, 1(2), 111-119. http://jurnalstkip- 
weetebula.ac.id/index.php/jppms/article /view/67

Kusumawardani, D. R., Wardono, W., \& Kartono, K. (2018, February). Pentingnya Penalaran Matematika dalam Meningkatkan Kemampuan Literasi Matematika. In PRISMA, Prosiding Seminar Nasional Matematika (Vol. 1, pp. 588-595). https://journal.unnes.ac.id/sju/index.php /prisma/article/view/20201

Lestari, S. Z. D., \& Roesdiana, L. (2021). ANALISIS KEMAMPUAN BERPIKIR KRITIS MATEMATIS SISWA SMP PADA MATERI HIMPUNAN. MAJU: Jurnal Ilmiah Pendidikan Matematika, 8(1). https://www.ejournal.stkipbbm.ac.id/in dex.php/mtk/article/view/611

Mahmuzah, R. (2015). Peningkatan Kemampuan Berpikir Kritis Matematis Siswa SMP Melalui Pendekatan Problem Posing. Jurnal Peluang, 4(1). http://202.4.186.66/peluang/article/view 15860

Mashuri, S. (2019). Media Pembelajaran Matematika - Yogyakarta: Deepublish Publisher. Google Scholar

Moleong, L. J. (2017). Metodologi Penelitian Kualitatif. Bandung: PT Remaja Rosdakarya. Google Scholar

Noor, N. L. A. (2019). Analisis Kemampuan Berpikir Kritis Matematis Ditinjau dari Gaya Kognitif Implusif dan Reflektif. Jurnal Pendidikan Matematika (Kudus), 2(1), 37-46. http://dx.doi.org/10.21043/jpm.v2i1.63 41

Nugroho, P. B. (2017). Scaffolding Meningkatkan Kemampuan Berpikir Kritis dalam Pembelajaran Matematika. Eksponen, 7(2), 1-10. https://doi.org/10.47637/eksponen.v7i2. 143
Nuryanti, L., Zubaidah, S., \& Diantoro, M. (2018). Analisis kemampuan berpikir kritis siswa SMP. Jurnal Pendidikan: Teori, Penelitian, dan Pengembangan, 3(2), 155-158. http://journal.um.ac.id/index.php/jptpp/ article/view/10490

Razak, F. (2017). Hubungan kemampuan awal terhadap kemampuan berpikir kritis matematika pada siswa kelas VII SMP Pesantren IMMIM Putri Minasatene. Mosharafa: Jurnal Pendidikan Matematika, 6(1), 117-128. https://doi.org/10.31980/mosharafa.v6i 1.299

Sholihah, I., \& Rejeki, S. (2020). Peningkatan Kemampuan Berpikir Kritis melalui Penerapan Pendekatan Pendidikan Matematika Realistik Indonesia (PMRI) pada Pembelajaran Himpunan. Kontinu: Jurnal Penelitian Didaktik Matematika, 4(1), 1-16. http://dx.doi.org/10.30659/kontinu.4.1. $1-16$

Siskandani, R., Novaliyosi, N., \& Rafianti, I. (2020). Analisis Kesalahan Siswa pada Soal Kemampuan Berpikir Kritis Materi Bangun Ruang Sisi Datar Kelas 8 SMP. Wilangan: Jurnal Inovasi dan Riset Pendidikan Matematika, 1(2), 128-134.

https://jurnal.untirta.ac.id/index.php/wil angan/article/view/8532

Sugiyono, P. D. (2017). Metode Penelitian Bisnis: Pendekatan Kuantitatif, Kualitatif, Kombinasi, dan R\&D. Penerbit CV. Alfabeta: Bandung. Google Scholar

Sulistiani, E., \& Masrukan, M. (2017, February). Pentingnya berpikir kritis dalam pembelajaran matematika untuk menghadapi tantangan MEA. In PRISMA, Prosiding Seminar Nasional Matematika (pp. 605-612). https://journal.unnes.ac.id/sju/index.php /prisma/article/view/21554 